\title{
PENYALURAN BANTUAN MODAL BRI DALAM PENINGKATAN PENDAPATAN PETANI PADI DI GAMPONG KERUMBOK AREE KECAMATAN DELIMA KABUPATEN PIDIE
}

\author{
Julia $^{(1)}$, Junaidi ${ }^{(2)}$, Anidar ${ }^{(3)}$ \\ Program Studi Agribisnis Fakultas Pertanian \\ Universitas Jabal Ghafur Sigli \\ Email : juliahasballah@gmail.com
}

\begin{abstract}
ABSTRAK
Penelitian ini bertujuan untuk mengetahui bantuan modal BRI terhadap peningkatan pendapatan petani padi di Gampong Kerumbok Aree Kecamatan Delima Kabupaten Pidie. Penelitian di mulai dari bulan November sampai dengan bulan Desember 2017 sampel dalam penelitian ini sebanyak 15 responden dari populasi 15 petani padi sawah yang menggunakan bantuan modal BRI di Gampong Keurumbok Aree Kecamatan Delima Kabupaten Pidie. Pengumpulan data menggunakan kuisioner dan selanjutnya data ditabulasi dan dijelaskan secara deskriptif. Metode yang digunakan dalam penelitian ini menggunakan metode analisis kualitatif. Hasil penelitian menunjukkan bahwa Modal BRI berpengaruh terhadap pendapatan petani padi di Gampong keurumbok Aree Kecamatan Delima Kabupaten Pidie. Hal ini dapat dilihat dari hasil rekapitulasi data dilapangan dengan rata-rata pendapatan petani sebelum mendapatkan pinjaman rata-rata sebesar Rp.1.180.000 dan sesudah mendapatkan pinjaman modal terjadi kenaikan pendapatan rata-rata sebesar RP. 2.326.000.

Kata Kunci : Modal BRI, Peningkatan Pendapatan
\end{abstract}

\section{PENDAHULUAN}

\section{Latar Belakang}

Tujuan pembangunan pertanian adalah untuk meningkatkan pendapatan petani yang diawali dengan usaha-usaha peningkatan produksi, dengan harapan produktivitas petani akan meningkat dengan meningkatnya produksi. Rendahnya tingkat produktivitas petani akan menghambat pembentukan modal karna dengan produktivitas yang rendah maka alokasi produktivitas lebih banyak ditujukan untuk pemenuhan konsumsi keluarga, dari pada untuk pembentukan modal di dalam bentuk investasi.

Pinjaman dari kreditor perorangan ini hanya mengatasi kesulitan dana untuk sementara waktu. Dana yang diperolehnya hanya dirasakan sesaat, sebab dengan meminjam dari sumber kredit perorangan kebanyakan penduduk pedesaan justru terjerat kesulitan baru. Sebagian besar sumber dana operasional bank berasal dari 
simpanan masyarakat, untuk itu keberhasilan dan kegagalan bank dalam mengelola kredit akan berpengaruh pada rakyat banyak yang menyimpan uangnya di bank. Memberikan kredit bukan merupakan pekerjaan yang mudah karena proses pemberian kredit yang baik akan banyak menentukan kualitas kredit itu sendiri.

Modal mutlak diperlukan dalam usaha pertanian. Tanpa modal, usaha sudah pasti tidak bisa dilakukan. Modal dibutuhkan untuk proses produksi. Kecukupan modal mempengaruhi kualitas dan kuantitas produk yang dihasilkan Kekurangan modal akan menyebabkan timbulnya risiko kegagalan atau rendahnya produksi. Pada dasarnya pemberian kredit diarahkan untuk meningkatkan produksi dengan mengutamakan pengusaha golongan lemah atau petani, dengan meningkatnya produksi diharapkan dapat terjadi peningkatan pendapatan petani. Untuk itu, pemerintah berperan dalam penciptaan program kredit bagi petani. Hal ini juga yang mendorong pemerintah Aceh memberikan bantuan modal bagi petani dalam bentuk kredit, yaitu bantuan modal BRI

Sejak tahun 2015 BRI meluncurkan program KUR Mikro yang memang ditujukan bagi para petani kecil dengan bunga yang sangat ringan yaitu $0,5 \%$, persyaratan kredit lebih mudah yaitu hanya melampirkan fotocopy KTP,kartu keluarga dan surat keterangan usaha dari Kepala Desa serta proses pengajuan dan pencairan kredit relatif cepat yaitu hanya sekitar 2 hari saja. KUR Mikro yang dirancang untuk membantu permodalan usaha tani ini bisa dimanfaatkan oleh semua pelaku utama di bidang pertanian, perkebunan, peternakan, perikanan, industri pengolahan hasil pertanian skala mikro dan perdagangan hasil pertanian.

Bank Rakyat Indonesia (BRI) merupakan satu-satunya lembaga keuangan yang menyediakan pembiayaan kepada Petani, seperti KUR dan KUR KKP-E yaitu produk kredit bank dengan skala mikro yang khusus untuk pembiayaan sektor pertanian. Visi BRI Cabang Delima yaitu menjadi Bank komersial terkemuka yang selalu mengutamakan kepuasan nasabah. Sebagai langkah realisasi dari visinya, salah satu misi BRI adalah memberikan pelayanan prima kepada nasabah melalui jaringan kerja yang terbesar luas dan didukung oleh sumber daya manusia yang profesional dengan melaksanakan praktek good coorporate governance. Kredit merupakan sumber utama penghasilan bagi bank dan sekaligus sumber operasi terbesar, sebagian besar dana operasional diputarkan dalam kredit. Bila kegiatan tersebut berhasil maka usaha bank pun berhasil. Namun bila bank banyak terjerat kredit bermasalah, hal ini akan berpengaruh besar bagi operasional bank. 


\section{METODE PENELITIAN \\ Sumber Data}

Penelitian ini dilakukan di

Gampong Keurumbok Aree

Kecamatan Delima Kabupaten Pidie

dengan pertimbangan bahwa

Gampong Keurumbok Aree

merupakan salah satu Gampong di

Kecamatan Delima Kabupaten Pidie

yang banyak terbentuk anggota

kelompok tani sebagai pengguna

modal BRI.

Pelaksanaan penelitian di mulai dari bulan Juli sampai dengan bulan September 2018.

\section{Metode Analisis}

Analisis data pada tahap ini mencakup penelaah data hasil pengamatan, wawancara dan dokumentasi mengenai bantuan modal BRI terhadap peningkatan pendapatan petani padi Di Gampong Keurumbok Aree Kecamatan Delima Kabupaten Pidie. Data yang diperoleh dianalisis dengan menajamkan, menggabungkan, mengarahkan, membuang yang tidak perlu dan mengorganisasikan data.

Penyajian Data

Pada bagian ini data dibuat menjadi sekumpulan informasi yang tersusun dan memberikan kemungkinan adanya penafsiran,penarikan kesimpulan dan pengambilan tindakan. Penyajian ini meliputi penyajian data hasil pengamatan,wawancara, angket dan dokumentasi yang berkaitan dengan Bantuan Modal BRI Terhadap Peningkatan Pendapatan Petani padi Di Gampong Keurumbok Aree Kecamatan Delima Kabupaten Pidie. Penarikan Kesimpulan

$$
\text { Penarikan kesimpulan }
$$

dilakukan untuk menafsirkan data analisis, sehingga memalui kegiatan ini diperoleh gambaran tentang Bantuan Modal BRI Terhadap Peningkatan Pendapatan Petani Padi Di Gampong Keurumbok Aree Kecamatan Delima Kabupaten Pidie.Adapun jawaban responden dari hasil kuesioner dihitung menggunakan rumus persentase. Rumus mencari persentase hasil kuesioner adalah :

$$
F=\frac{f}{\pi l} \times 100
$$

Dimana :

$\mathrm{p}=$ Persentase

$\mathrm{f}=$ Frekwensi

$\mathrm{n}=$ Jumlah responden

\section{PEMBAHASAN}

\section{Gambaran Lokasi Penelitian}

Kecamatan

Delima

merupakan salah satu dari 23 kecamatan yang ada di Kabupaten Pidie. Luas keseluruhan Kecamatan Delima adalah $43.89 \mathrm{Km} 2$ (4.389) Ha.

\section{Karakteristik Responden}

Jumlah responden yang ditetapkan sebagai responden penelitian sebanyak 15 orang. Informasi karakteristik responden didasarkan pada jawaban yang diperoleh peneliti dari hasil penyebaran kuesioner meliputi jenis kelamin, usia, status, pendidikan terakhir dan jumlah tanggungan keluarga.

\section{Keadaaan Responden Menurut} Usia

Usia responden dalam penelitian ini dikelompokkan kedalam 3 rentang angka. Adapun rincian kelompok usia dan jumlahnya dapat dilihat pada tabel berikut: 
Tabel 4. Keadaaan Responden Menurut Usia di di Daerah Penelitian, Tahun 2018

\begin{tabular}{ccc} 
Kelompok Usia (Tahun) & $\begin{array}{c}\text { Jumlah Responden } \\
\text { (orang) }\end{array}$ & $\begin{array}{c}\text { Persentase } \\
(\boldsymbol{\%})\end{array}$ \\
$\mathbf{4} \mathbf{3 5}$ & 3 & 20 \\
$\mathbf{3 6}-\mathbf{4 5}$ & 4 & 26 \\
$\mathbf{4 6} \mathbf{- 5 5}$ & 5 & 33 \\
$>\mathbf{5 5}$ & 3 & 20 \\
Jumlah & 15 & 100 \\
\hline
\end{tabular}

Sumber: Data Primer diolah, 2018

Berdasarkan Tabel 4 terlihat bahwa usia responden paling banyak pada kelompok 46-55 tahun yaitu 33 $\%$ kemudian kelompok usia 36-45 tahun sebanyak $26 \%$ sedangkan sisanya berada pada kelompok usia < 35 tahun dan $>55$ sebesar $20 \%$. Hal ini menunjukkan bahwa responden di daerah penelitian merupakan kelompok usia produktif. Dengan usia yang masih tergolong produktif mempengaruhi pola pikir responden dan semangat kerja pun masih terlalu tinggi sehingga responden mudah menentukan pilihan untuk mencari cara dalam meningkatkan pendapatan keluarga.

Responden Menurut Pendidikan

Tingkat pendidikan yang dimiliki responden terdiri dari tingkat SD, SMP,SMA dan sarjana. Adapun persentase jumlah dari tingkat pendidikan dapat dilihat pada tabel berikut:

Tabel 5. Keadaan Responden Menurut Pendidikandi Daerah Penelitian, Tahun 2018

\begin{tabular}{lcc}
\hline \multicolumn{1}{c}{ Pendidikan } & $\begin{array}{c}\text { Jumlah Responden } \\
\text { (orang) }\end{array}$ & $\begin{array}{c}\text { Persentase } \\
(\boldsymbol{\%})\end{array}$ \\
Tidak tamat SD & 2 & 13 \\
SD & 3 & 20 \\
SMP & 5 & 33 \\
SMA & 4 & 26 \\
Diploma/Sarjana & 1 & 6 \\
$\quad$ Jumlah & 15 & 100 \\
\hline
\end{tabular}

Sumber: Data Primer diolah, 2018

Data pada tabel 5 terlihat bahwa tingkat pendidikan yang berhasil diselesaikan responden paling banyak adalah SMP dengan persentase sebesar $33 \%$, SMA sebesar $26 \%$, dan yang lulusan SD $20 \%$, sedangkan yang tidak tamat SD $13 \%$ sisanya $6 \%$ merupakan lulusan Diploma/sarjana. Pendidikan berkaitan dengan kemampuan seseorang dalam mengelola sumber daya sehingga menentukan ketepatan

alokasi dari sumber daya yang dimiliki guna memperoleh pendapatan.

Keadaan Responden Menurut Jumlah Tanggungan Keluarga Jumlah tanggungan responden dalam penelitian ini dikelompokkan dalam 3 rentang bagian. Adapun persentase dari tanggungan dapat dilihat pada tabel berikut: 
Tabel 6. Keadaan Responden Menurut Jumlah Tanggungandi Daerah Penelitian, Tahun 2018

\begin{tabular}{ccc}
\hline $\begin{array}{c}\text { Jumlah Tanggungan } \\
\text { (orang) }\end{array}$ & $\begin{array}{c}\text { Jumlah Responden } \\
\text { (orang) }\end{array}$ & $\begin{array}{c}\text { Persentase } \\
(\boldsymbol{\%})\end{array}$ \\
$\begin{array}{c}\text { Tidak ada tanggungan } \\
\text { keluarga }\end{array}$ & 1 & 6 \\
1 orang & 2 & 13 \\
$\mathbf{2}$ orang & 3 & 20 \\
3 orang & 5 & 33 \\
>3 orang, sebutkan... orang & 4 & 26 \\
Jumlah & 15 & 100 \\
\hline
\end{tabular}

Sumber: Data Primer diolah, 2018

Data pada Tabel 6 menunjukkan bahwa tanggungan keluarga paling banyak 3 orang dengan persentase $33 \%$, yang memiliki tanggungan $>3$ orang sebanyak $26 \%$, sisanya sebanyak $20 \%$ memiliki jumlah tanggungan 2 orang,kemudian $6 \%$ tidak memiliki tanggungan, sedangkan 13\% memiliki jumlah tanggungan 1 orang. Semakin banyak jumlah tanggungan semakin banyak kebutuhan konsumsi yang harus dipenuhi. Jumlah tanggungan dalam suatu rumah tangga juga dapat mempengaruhi seseorang dalam bekerja, mencari nafkah untuk menanggapi kesejahteraan anggota keluarganya.

\section{Penyaluran Modal BRI}

Modal BRI adalah bantuan modal yang diberikan oleh pemerintah kepada daerah yang memiliki potensi di bidang perekonomian dan pertanian. Desa Keureumbok Kecamatan Delima Kabupaten Pidie merupakan salah satu daerah yang penduduknya bermata pencaharian sebagai petani. Modal BRI diharapkan dapat membantu petani agar berhasil mengelola usaha pertaniannya sehingga dapat meningkatkan produksi dan akhirnya dapat meningkatkan pendapatan.

Pengaruh modal BRI dalam penelitian ini dijelaskan dalam 14 indikator. Adapun rincian persentase untuk setiap indikator dapat dilihat pada tabel-tabel berikut:

Tabel 7. Indikator Sumber Informasi Bantuan Modaldi Daerah Penelitian, Tahun 2018

\begin{tabular}{lcc}
\hline \multicolumn{1}{c}{ Sumber Informasi } & $\begin{array}{c}\text { Jumlah Responden } \\
\text { (Orang) }\end{array}$ & $\begin{array}{c}\text { Persentase } \\
(\%)\end{array}$ \\
Dari teman & 6 & 40 \\
Mencari Informasi Sendiri & 2 & 13 \\
Dari Petugas Penyuluh & 7 & 46 \\
Dari Iklan & 0 & 0 \\
\multicolumn{1}{c}{ Jumlah } & 15 & 100 \\
\hline
\end{tabular}

Sumber: Data Primer diolah, 2018 
Dari tabel 7 dapat dijelaskan bahwa responden mendapatkan sumber informasi bantuan pinjaman modal BRI dari teman sebanyak $40 \%$ kemudian responden yang mendapatkan sumber informasi dari petugas penyuluh sebanyak $46 \%$ dan responden yang meencari informasi sendiri sebanyak $13 \%$ serta responden yang mendapatkan

Tabel 8. Indikator Kemudahan Mengakses Informasidi Daerah Penelitian, Tahun 2018

\begin{tabular}{lcc}
\hline \multicolumn{1}{c}{ Kemudahan } & $\begin{array}{c}\text { Jumlah Responden } \\
\text { (Orang) }\end{array}$ & $\begin{array}{c}\text { Persentase } \\
(\boldsymbol{\%})\end{array}$ \\
Sangat Mudah & 4 & 26 \\
Mudah & 9 & 60 \\
Cukup Mudah & 2 & 13 \\
Sangat Tidak Mudah $\quad$ Jumlah & 0 & 0 \\
\multicolumn{1}{c}{ (Ond } & 15 & 100 \\
\hline
\end{tabular}

Sumber: Data Primer diolah, 2018

Dari tabel 8 dapat dijelaskan bahwa responden yang mengakses informasi modal BRI secara mudah sebanyak $60 \%$ kemudian responden yang mengakses informasi modal BRI secara sangat mudah sebanyak $26 \%$ dan responden yang mengakses informasi modal BRI secara cukup sumber informasi dari iklan sebanyak $0 \%$.

Hal ini menunjukkan bahwa kurangnya pemberitahuan dan promosi dari media iklan sehingga responden lebih mendapatkan informasi bantuan pinjaman modal BRIdari teman walaupun ada juga dari petugas penyuluh.

Tabel 9. Indikator Lama Memanfaatkan Pinjaman Modaldi Daerah Penelitian, Tahun 2018

\begin{tabular}{|c|c|c|}
\hline $\begin{array}{c}\text { Lama Memanfaatkan } \\
\text { (Tahun) }\end{array}$ & $\begin{array}{c}\text { Jumlah Responden } \\
\text { (Orang) }\end{array}$ & $\begin{array}{l}\text { Persentase } \\
(\%)\end{array}$ \\
\hline$<1$ Tahun & 2 & 13 \\
\hline 1-3 Tahun & 11 & 73 \\
\hline 3-5 Tahun & 2 & 13 \\
\hline > 5 Tahun & 0 & 0 \\
\hline Jumlah & 15 & 100 \\
\hline
\end{tabular}

Sumber: Data Primer diolah, 2018

Dari tabel 9 dapat dijelaskan bahwa responden yang sudah memanfaatkan pinjaman modal BRI selama 1-3 tahun sebanyak $73 \%$ kemudian responden yang sudah memanfaatkan pinjaman modal BRI mudah sebanyak $13 \%$, sedangkan responden yang mengakses informasi modal BRI secara tidak mudah sebanyak $0 \%$.Hal ini menunjukkan bahwa modal BRI diinformasikan secara terbuka diketahui oleh umum sehingga mudah untuk diakses masyarakat. 
modal BRIselama > 5 tahun sebanyak $0 \%$ Hal ini menunjukkan bahwa bantuan modal BRIsudah lama dimanfaatkan oleh masyarakat khususnya petani karena program tersebut bukan merupakan program yang baru dikalangan masyarakat.

Tabel 10. Indikator Peran Pinjaman Modal Mengelola Usaha Tanidi Daerah Penelitian, Tahun 2018

\begin{tabular}{lcc}
\hline \multicolumn{1}{c}{ Peran } & $\begin{array}{c}\text { Jumlah Responden } \\
\text { (Orang) }\end{array}$ & $\begin{array}{c}\text { Persentase } \\
(\boldsymbol{\%})\end{array}$ \\
Ya, membantu & 9 & 60 \\
Tidak Membantu & 0 & 0 \\
Sangat Membantu & 5 & 33 \\
Tidak terlalu membantu & 1 & 6 \\
Jumlah & 15 & 100 \\
\hline
\end{tabular}

Sumber: Data Primer diolah, 2018

Dari tabel 10 dapat dijelaskan sebanyak $60 \%$ responden dari jumlah keseluruhan yang ada mengatakan bahwa pinjaman modal kelompok BRI berperan dalam membatu usaha tani kemudian $33 \%$ responden mengatakan bahwa pinjaman modal BRI sangat

Tabel 11. Indikator Ketepatan Waktu Pinjaman ModalBRIdi Daerah Penelitian, Tahun 2018

\begin{tabular}{|c|c|c|}
\hline Ketepatan Waktu & $\begin{array}{l}\text { Jumlah Responden } \\
\text { (Orang) }\end{array}$ & $\begin{array}{l}\text { Persentase } \\
(\%)\end{array}$ \\
\hline Tepat waktu & 6 & 40 \\
\hline Dana Terlambat & 0 & 0 \\
\hline Sering Terlambat & 0 & 0 \\
\hline $\begin{array}{l}\text { Kadang Tepat Waktu/kadang } \\
\text { terlambat }\end{array}$ & 9 & 60 \\
\hline Jumlah & 15 & 100 \\
\hline
\end{tabular}

Sumber: Data Primer diolah, 2018

Dari tabel 11 menjelaskan sebanyak $60 \%$ responden mengatakan bahwa pinjaman modal BRI kadang diberikan tepat waktu kemudian $40 \%$ responden mengatakan bahwa pinjaman modal BRI selalu diberikan tepat waktu, sedangkan $0 \quad \% \quad$ responden mengatakan bahwa bantuan membatu usaha tani. Sisanya $6 \%$ mengatakan tidak terlalu membantu dan $0 \%$ mengatakan tidak membantu. Hal ini menjelaskan bahwa pinjaman modal BRI berpengaruh terhadap usaha tani walaupun perannya tidak seberapa.

pinjaman modal BRI diberikan
terlambat. Hal ini menunjukkan
bantuan pinjaman modal BRI
diberikan tepat disaat petani
membutuhkan modal dalam
usahataninya.


Tabel 12. Indikator Bantuan Pinjaman Modal sudah Memadaidi Daerah Penelitian, Tahun 2018

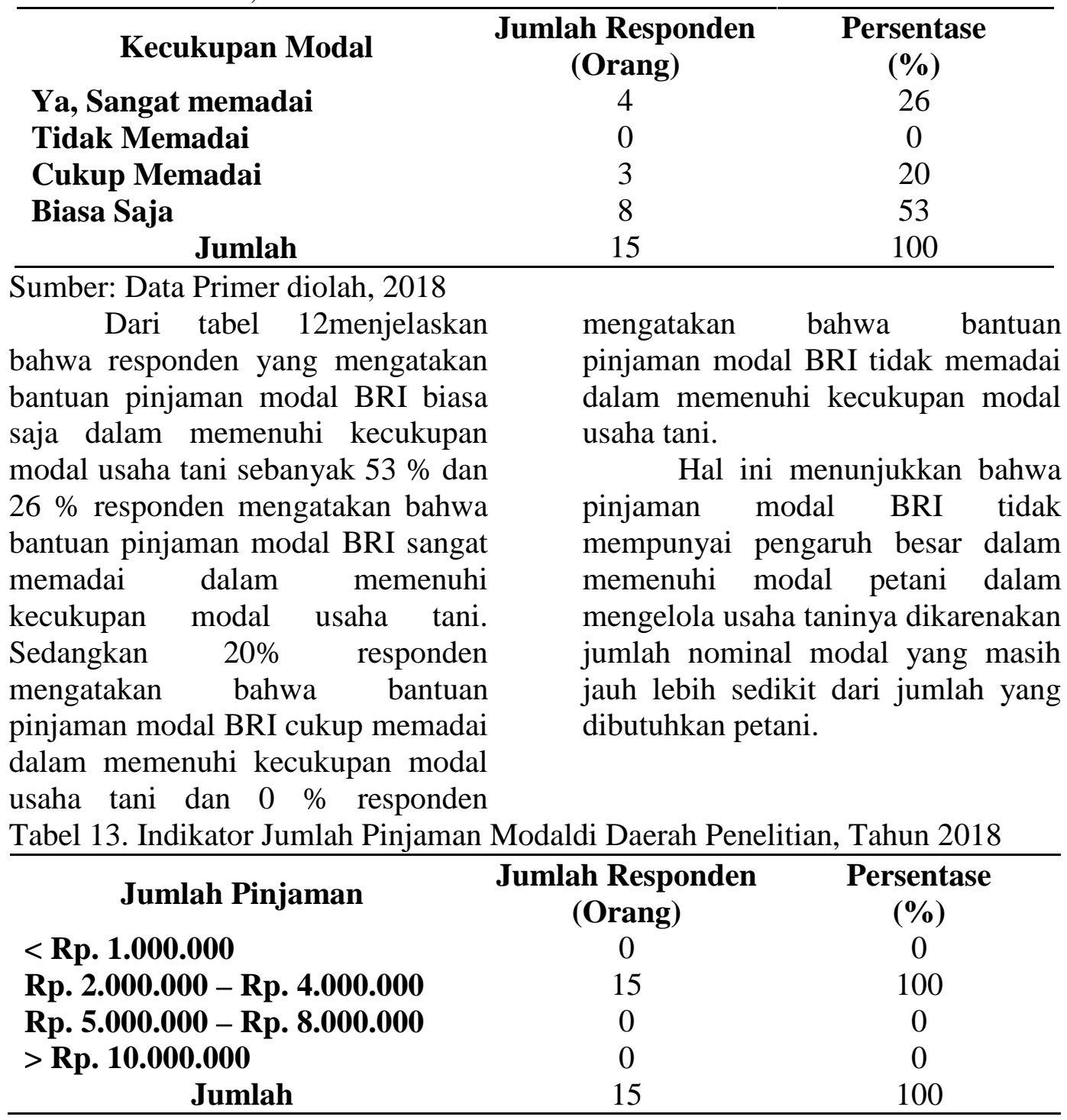

Sumber: Data Primer diolah, 2018

$\begin{array}{lll}\text { Dari uraian tabel } 13 & \text { Rp.3.000.000 dan > Rp.3.000.000. } \\ \text { menunjukkan bahwa } 100 \% & \text { Hal ini menunjukkan bahwa } \\ \text { responden meminjam modal BRI } & \text { pinjaman modal BRI hanya diberikan } \\ \text { sebesar Rp. } 2.000 .000-\text { Rp. } 4.000 .000 . & \text { berdasarkan luas lahan yang dimiliki } \\ \text { Sedangkan } 0 \quad \% \text { responden } & \text { petani dan diberikan dalam per } \\ \text { meminjam modal BRI sebesar }< & \text { musim tanam. }\end{array}$
Rp.1.000.000 , Rp.2.000.000- 
Tabel 14. Indikator Sistem Angsuran Pinjaman Modaldi Daerah Penelitian, Tahun 2018

\begin{tabular}{|c|c|c|}
\hline Sistem Angsuran & $\begin{array}{c}\text { Jumlah Responden } \\
\text { (Orang) }\end{array}$ & $\begin{array}{c}\text { Persentase } \\
(\%)\end{array}$ \\
\hline Harian & 0 & 0 \\
\hline Mingguan & 0 & 0 \\
\hline Bulanan & 15 & 100 \\
\hline Tahunan & 0 & 0 \\
\hline Jumlah & 15 & 100 \\
\hline
\end{tabular}

Sumber: Data Primer diolah, 2018

Dari tabel 14 menjelaskan bahwa $100 \%$ responden mengatakan bahwa sistem angsuran pinjaman modal BRI dibayar dalam bulanan dan $0 \%$ responden mengatakan bahwa sistem angsuran pinjaman modal BRI dibayar dalam harian,

Tabel 15. Indikator Cara Mengangsur Pinjaman Modal BRIdi Daerah Penelitian, Tahun 2018

\begin{tabular}{lcc}
\hline \multicolumn{1}{c}{ Cara Angsuran } & $\begin{array}{c}\text { Jumlah Responden } \\
\text { (Orang) }\end{array}$ & $\begin{array}{c}\text { Persentase } \\
(\boldsymbol{\%})\end{array}$ \\
Datang Sendiri & 12 & 80 \\
Petugas Datang Sendiri & 0 & 0 \\
Saat Rapat kelompok & 0 & 0 \\
Menitip pada Sesama Anggota & 3 & 20 \\
\multicolumn{1}{c}{ Jumlah } & 15 & 100 \\
\hline
\end{tabular}

Sumber: Data Primer diolah, 2018

Penjelasan dari tabel 15 menunjukkan bahwa $80 \%$ responden mengangsur pinjaman modal BRI dengan cara datang sendiri dan $20 \%$ responden menitip pada sesama mingguan dan tahunan. Hal ini menjelaskan bahwa petani melakukan sistem angsuran pinjaman modal BRI secara bulanan karena petani berpenghasilan hanya pada waktu musim panen.

Tabel 16. Indikator Besarnya Bunga Pinjaman Modal BRIdi Daerah Penelitian, Tahun 2018

\begin{tabular}{|c|c|c|}
\hline Besarnya Bunga & $\begin{array}{c}\text { Jumlah Responden } \\
\text { (Orang) }\end{array}$ & $\begin{array}{c}\text { Persentase } \\
(\%)\end{array}$ \\
\hline $0,5 \%$ & 15 & 100 \\
\hline $5 \%-10 \%$ & 0 & 0 \\
\hline $10 \%-12 \%$ & 0 & 0 \\
\hline$>12 \%$ & 0 & 0 \\
\hline Jumlah & 15 & 100 \\
\hline
\end{tabular}

Sumber: Data Primer diolah, 2018 
Berdasarkan tabel 16 dapat diketahui bahwa sebanyak $100 \%$ dari jumlah keseluruhan yang ada responden membayar bunga pinjaman modal BRI sebesar 5\% dan $0 \%$ responden membayar besarnya bunga sebesar $5 \%-10 \%, 10 \%-12$

Tabel 17. Indikator Beban Besaran Bunga dalam Angsuran Pinjamandi Daerah Penelitian, Tahun 2018

\begin{tabular}{lcc}
\hline \multicolumn{1}{c}{ Beban Besaran Bunga } & $\begin{array}{c}\text { Jumlah Responden } \\
\text { (Orang) }\end{array}$ & $\begin{array}{c}\text { Persentase } \\
(\boldsymbol{\%})\end{array}$ \\
Ya, Sangat Terbeban & 2 & 13 \\
Tidak Terbeban & 3 & 20 \\
Cukup Terbeban & 3 & 20 \\
Biasa Saja & 7 & 46 \\
$\quad$ Jumlah & 15 & 100 \\
\hline
\end{tabular}

Sumber: Data Primer diolah, 2018

Dari tabel 17 dijelaskan bahwa $46 \%$ responden mengatakan bahwa beban besaran bunga dalam angsuran pinjaman modal BRI merupakan hal yang biasa saja dan $13 \%$ responden mengatakan sangat terbeban. Sedangkan $20 \%$ responden mengatakan bahwa beban besaran bunga dalam angsuran pinjaman

Tabel 18. Indikator Kegunaan Pinjaman Modal BRIdi Daerah Penelitian, Tahun 2018

\begin{tabular}{lcc}
\hline \multicolumn{1}{c}{ Kegunaan } & $\begin{array}{c}\text { Jumlah Responden } \\
\text { (Orang) }\end{array}$ & $\begin{array}{c}\text { Persentase } \\
(\%)\end{array}$ \\
Membayar Hutang & 0 & 0 \\
Mencukupi kebutuhan keluarga & 3 & 20 \\
Membayar Sekolah Anak & 2 & 13 \\
Menambah modal usaha tani & 10 & 66 \\
\multicolumn{1}{c}{ Jumlah } & 15 & 100 \\
\hline
\end{tabular}

Sumber: Data Primer diolah, 2018

Berdasarkan tabel 18 dijelaskan bahwa $66 \%$ responden menggunakan pinjaman modal BRI untuk menambah modal usaha tani dan 20 digunakan untuk mencukupi kebutuhan keluarga. Sedangkan 13 $\%$ responden menggunakan pinjaman
$\%$ dan $>12 \%$. Hal ini menunjukkan bahwa besarnya bunga pinjaman modal BRI yang harus dibayar petani tidaklah besar karena petani hanya diperbolehkan meminjam dengan nominal yang sesuai dengan luas lahan yang dimiliki. modal BRI merupakan cukup terbeban dan tidak terbeban. Hal ini menunjukkan bahwa petani tidak merasa dibebani dan bersifat netral terhadap besaran bunga pinjaman modal BRI karena besaran bunga yang diberlakukan sesuai dengan modal yang mereka pinjamkan. 
Tabel 19. Indikator Kesulitan Dalam Mengangsur Pinjaman Modal BRIdi Daerah Penelitian, Tahun 2018

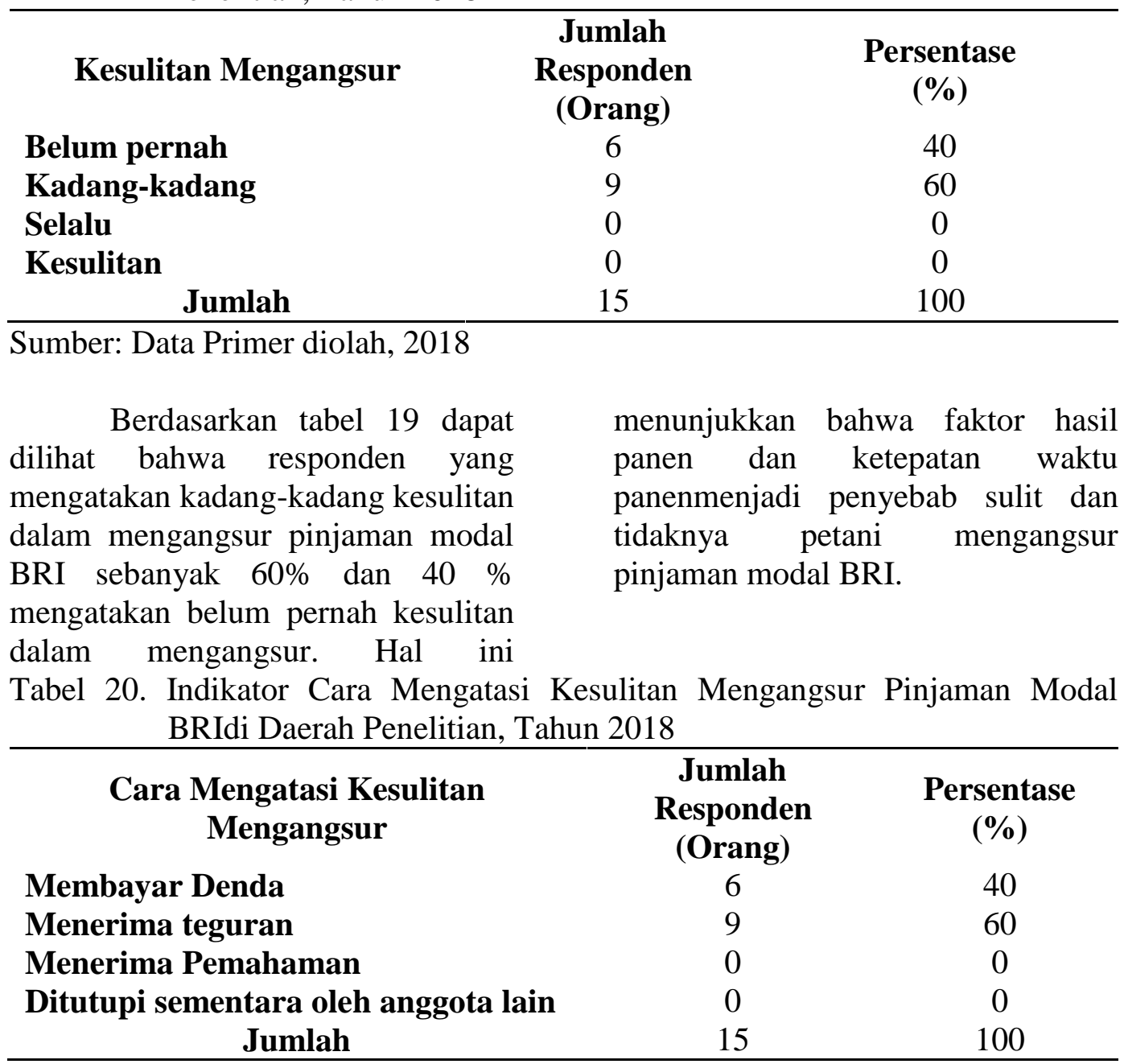

Sumber: Data Primer diolah, 2018

Dari tabel 20 dijelaskan bahwa $60 \%$ responden mengatakan menerima teguran jika kesulitan mengangsur pinjaman modal BRI dan $40 \%$ responden mengatakan membayar denda. Sedangkan $0 \%$ responden mengatakan menerima pemahaman dan ditutupi sementara oleh anggota lain jika kesulitan dalam mengangsur pinjaman. Hal ini menunjukkan bahwa petani mematuhi semua peraturan yang sudah disepakati dalam proses pinjaman dengan menerima sanksi apabila terjadi keterlambatan dalam angsuran.

\subsection{Peningkatan Pendapatan Petani}

Setelah melakukan pinjaman modal BRI, Peningkatan pendapatan yang tidak terlalu besar ini terjadi akibat perubahan dari modal BRI yang dipinjam oleh responden dalam mengelola usaha tani. Pendapatan yang sedikit meningkat harus disesuaikan dengan pengeluaran yang masih sama dengan tahun sebelumnya sehingga peningkatan pendapatan tidak terlalu besar.Peningkatan pendapatan petani 
akibat modal BRI dalam penelitian ini dijelaskan dalam 6 indikator. Adapun rincian persentase untuk Tabel 21. Indikator Pendapatan Rata-Rata Sebelum Mendapatkan Pinjaman Modal di Daerah Penelitian, Tahun 2018

\begin{tabular}{lcc}
\hline \multicolumn{1}{c}{ Pendapatan } & $\begin{array}{c}\text { Jumlah } \\
\text { Responden } \\
\text { (Orang) }\end{array}$ & $\begin{array}{c}\text { Persentase } \\
(\%)\end{array}$ \\
< Rp. 50.000 & 0 & 0 \\
Rp. 500.000 - Rp. 1.000.000 & 4 & 26 \\
Rp. 1.000.000 - Rp. 2.000.000 & 11 & 73 \\
> Rp. 2.000.000 & 0 & 0 \\
Jumlah & 15 & 100 \\
\hline
\end{tabular}

Sumber: Data Primer diolah, 2018

Dari tabel 21 menjelaskan bahwa $73 \%$ responden mengatakan bahwa pendapatan rata-rata sebelum mendapatkan pinjaman modal BRI berjumlah Rp. 1.000 .000 - Rp. 2.000 .000 dan $26 \%$ berpendapatan Rp. Rp. 500.000 - Rp. 1.000.000. setiap indikator dapat dilihat pada tabel-tabel berikut:

Tabel 22. Indikator Pendapatan Rata-rata Setelah Mendapatkan Pinjaman Modal di Daerah Penelitian, Tahun 2018

\begin{tabular}{ccc}
\hline \multicolumn{1}{c}{ Pendapatan } & $\begin{array}{c}\text { Jumlah } \\
\text { Responden } \\
\text { (Orang) }\end{array}$ & $\begin{array}{c}\text { Persentase } \\
(\%)\end{array}$ \\
< Rp. 1.000.000 & 0 & 0 \\
Rp. 1.000.000 - Rp. 2.000.000 & 3 & 20 \\
Rp. 2.000.000 - Rp. 3.000.000 & 12 & 80 \\
> Rp. 3.000.000 & 0 & 0 \\
Jumlah & 15 & 100 \\
\hline
\end{tabular}

Sumber: Data Primer diolah, 2018

Dari tabel 22 menjelaskan bahwa $80 \%$ responden mengatakan bahwa pendapatan rata-rata setelah mendapatkan pinjaman modal BRI berjumlah Rp. 2.000.000 - Rp. 3.000 .000 dan $20 \%$ berpendapatan Hal ini menjukkan bahwa pendapatan petani tergolong kecil sebelum melakukan pinjaman modal BRI dikarenakan usaha tani yang tidak memadai dikarenakan terbatasnya modal dalam mengelola usaha tani.

Rp. 1.000 .000 - Rp. 2.000.000. Hal

ini menunjukkan bahwa pendapatan petani meningkat setelah melakukan pinjaman modal BRI dikarenakan dengan tambahan modal maka petani dapat meningkatkan hasil produksi dari usaha tani. 
Tabel 23. Indikator Pendapatan Memenuhi Kebutuhan Hidup Keluargadi Daerah Penelitian, Tahun 2018

\begin{tabular}{lcc}
\hline Memenuhi Kebutuhan Hidup & $\begin{array}{c}\text { Jumlah } \\
\text { Responden } \\
\text { (Orang) }\end{array}$ & Persentase (\%) \\
Dapat memenuhi & 1 & 6 \\
Tidak Dapat memenuhi & 0 & 0 \\
Belum Dapat Memenuhi & 9 & 60 \\
Pernah Memenuhi & 5 & 33 \\
\multicolumn{1}{c}{ Jumlah } & 15 & 100 \\
\hline
\end{tabular}

Sumber: Data Primer diolah, 2018

Dari tabel 23 menjelaskan bahwa $60 \%$ responden mengatakan pendapatan belum dapat memenuhi kebutuhan keluarga dan $33 \%$ mengatakan pernah memenuhi kebutuhan keluarga. Sedangkan $6 \%$ responden mengatakan bahwa pendapatan dapat memenuhi kebutuhan keluarga. Hal ini menunjukkan meskipun pendapatan petani sudah meningkat karena pinjaman modal BRI namun pendapatan yang diterima belum dapat memenuhi kebutuhan hidup keluarga karena kebutuhan hidup yang mahal dengan pengeluaran yang hampir sebanding dengan pendapatan.

Tabel 24. Indikator Pendapatan Sampingan setelah mendapatkan bantuan Modaldi Daerah Penelitian, Tahun 2018

\begin{tabular}{lcc}
\hline Mencari pendapatan sampingan & $\begin{array}{c}\text { Jumlah } \\
\text { Responden } \\
\text { (Orang) }\end{array}$ & $\begin{array}{c}\text { Persentase } \\
(\%)\end{array}$ \\
$\begin{array}{l}\text { Masih Mencari } \\
\text { Tidak Mencari Lagi }\end{array}$ & 7 & 46 \\
$\begin{array}{l}\text { Kadang-Kadang/Sesekali } \\
\text { mencari }\end{array}$ & 5 & 20 \\
$\quad$ Jumlah & 15 & 33 \\
\hline
\end{tabular}

Sumber: Data Primer diolah, 2018

Dari tabel 24 menunjukkan bahwa responden yang masih mencari pendapatan sampingan berjumlah $46 \%$ dan $33 \%$ responden mengatakan kadang-kadang membutuhkan pendapatan sampingan. Sedangkan $20 \quad \%$ responden yang tidak mencari pendapatan sampingan setelah mendapatkan pinjaman modal BRI.
Hal ini menjelaskan petani membutuhkan pekerjaan sampingan selain bertani untuk memenuhi kebutuhan hidup dan menyisakan pendapatannya menjadi tabungan untuk keperluan dimasa depan. 
Tabel 25. Indikator Pendapatan Tambahan dari saudara yang laindi Daerah Penelitian, Tahun 2018

\begin{tabular}{|c|c|c|}
\hline Tambahan Pendapatan & $\begin{array}{c}\text { Jumlah Responden } \\
\text { (Orang) }\end{array}$ & $\begin{array}{c}\text { Persentase } \\
(\%)\end{array}$ \\
\hline Hanya satu kali & 1 & 6 \\
\hline Tidak pernah & 12 & \\
\hline Sering kali & 0 & 0 \\
\hline Lebih dari satu kali & 2 & 13 \\
\hline & 15 & \\
\hline \multicolumn{3}{|c|}{$\begin{array}{ll}\text { Sumber: Data Primer diolah, } 2018 & \\
\text { Dari tabel 25 menjelaskan } & \text { kali mendapatkan tambahan } \\
\text { bahwa } 80 \% \text { responden mengatakan } & \text { pendapatan. Hal ini menunjukkan } \\
\text { tidak mendapatkan tambahan } & \text { petani yang juga berperan sebagai } \\
\text { pendapatan dari saudara yang lain } & \text { kepala keluarga tidak memaksakan } \\
\text { setelah mendapatkan bantuan modal } & \text { anggota keluarga untuk mencari } \\
\text { dan 13\% responden mengatakan } & \text { pekerjaan sampingan karena untuk } \\
\text { lebih dari satu kali mendapatkan } & \text { mendapatkan pendapatan tambahan } \\
\text { tambahan pendapatan. Sedangkan } 6 & \text { petani dapat menggandakan mata } \\
\% \text { responden mengatakan hanya satu } & \text { pencaharian sebagai buruh bangunan. } \\
\text { Tabel 26. Indikator Kondisi Ekonomi Setelah Mendapatkan Pinjaman Modaldi } \\
\text { Daerah Penelitian, Tahun 2018 }\end{array}$} \\
\hline Kondisi Ekonomi & $\begin{array}{c}\text { Jumlah Responden } \\
\text { (Orang) }\end{array}$ & $\begin{array}{c}\text { Persentase } \\
(\%)\end{array}$ \\
\hline Men & 9 & 60 \\
\hline Tidak le & 2 & 13 \\
\hline Tetap s & 4 & 26 \\
\hline Pendapatan $\mathbf{m}$ & 0 & 0 \\
\hline Jumlah & & \\
\hline
\end{tabular}

Sumber: Data Primer diolah, 2018

Dari tabel 26 menjelaskan bahwa $60 \%$ responden mengatakan kondisi ekonomi menjadi lebih baik setelah mendapatkan pinjaman modal BRI dan $20 \%$ responden mengatakan kondisi ekonomi tetap seperti semula. Sedangkan $13 \%$ responden mengatakan kondisi ekonomi tidak lebih baik. Hal ini menunjukkan bahwa kondisi ekonomi petani setelah mendapatakan pinjaman modal BRI menjadi lebih baik karena adanya perubahan pendapatan meskipun peningkatannya tidak terlalu besar.

\section{KESIMPULAN DAN SARAN Kesimpulan}

Modal BRI berpengaruh terhadap pendapatan petani padi di Gampong keurumbok Aree Kecamatan Delima Kabupaten Pidie. Hal ini dapat dilihat dari hasil rekapitulasi data dilapangan dengan rata-rata pendapatan petani sebelum mendapatkan pinjaaman rata-rata sebesar Rp.1.180.000 dan sesudah mendapatkan pinjaman modal terjadi kenaikan pendapatan rata-rata sebesar RP. 2.326.000. 


\section{Saran}

1. Kepada Penyuluh Pertanian Lapangan Sebaiknya dilakukan pembinaan terhadap petanipetani penerima modal BRI tentang modal BRI dalam pengelolaan usahanya dan pembinaan terhadap kelancaran administrasi pengembalian modal BRI.

2. Kepada Pemerintah Program modal BRI ini untuk seterusnya dapat tetap diberikan kepada petani di Kecamatan Delima,karena tujuan yang diharapkan dapat tercapai

3. Kepada Peneliti Selanjutnya Agar dilakukan penelitian selanjutnya mengenai faktorfaktor terjadinya penunggakan pengembalian modal BRI.

\section{DAFTAR PUSTAKA}

Affandi, Riyanto. 2010. Pengantar Ekonomi Pertanian. Bumi Aksara : Jakarta.

Anonimus, 2005. Program Peningkatan Ekonomi Kerakyatan Melalui Pinjaman Modal Usaha dengan Pola Dana Bergulir Kabupaten Lampung Tengah. Lampung Tengah. (http://lampungtengah.go.id/u ploadfiles/Kep.Bupati No. 04 20005.pdf).

Arsyad, Muhammad 2004. Lembaga Keuangan Dan Pembiayaan. Citra Aditya Bakti. Bandung.

Daniel, M. 2010. Metode Penelitian Sosial Ekonomi. Bumi Aksara : Jakarta.
Dica Suci Enggar Jati. 2015. Pengaruh Pemberian Kredit Modal Kerja Terhadap Tingkat Pendapatan Usaha Kecil Dan Menegah (UKM) pada PT. Bank Pembiayaan Rakyat Syari'ah (BPRS) Margirizki Bahagia Bantul

Djojohadikusumo,S. 2009. Kredit Untuk Rakyat Di Masa Depresi. LP3ES : Jakarta

Elfindri dan A. Zein. 2001. "Kredit Untuk Nelayan dan Perbaikan Manajemen". Jurnal Ekonomi dan Pembangunan. IX(2).

Ghozali. 2005. Pengantar Metode Penelitian. Penerjemah : A. Tuwu. UI Press. Jakarta.

Gunardi, H. S. 2004. Kredit Rakyat : Dari Mekanisme Arisan Hingga BPR. Akatiga : Jakarta

Hanani, N., J. T. Ibrahim, dan M. Purnomo., 2003. Strategi Pembangunan Pertanian. Lappera Pustaka Utama : Yogyakarta.

Haris, Muhammad. 2010. Efektivitas Pelaksanaan Pinjmaan Dana PNPM mandiri Perdesaan. Skripsi. Universitas Indonesia. Jakarta.

Indrajaya, Putra. 2009. Dampak PNPM terhadap peningkatan pendapatan. Skripsi. ITB. Bandung. 
JAR,Volume 3 Nomor 2 Agustus 2020 $p$-ISSN 2615-417X, $e$-ISSN 2721-0782

Kirana, Dian. 2012. Efektivitas

Pelaksanaan Pinjmaan

Dana PNPM mandiri

PeGampongaan. Skripsi. Universitas Hassanudin.

Makassar.

Lely, Wirarti. 2007. Pertanian Pada Abad Ke-21. Direktorat Jenderal. Jakarta 